\title{
Demystifying Theory
}

\author{
HeatherBrunskell-Evans \\ School of Education
}

\section{Introduction}

A seminar series in the School of Education initiated by myself, together with Professor Andrew Lambirth, Dr Priti Chopra and Anna Kilderry, acts as a forum where colleagues discuss the theoretical background that informs their practice as educationalists. If I may be permitted to speak here for the core group, each one of us has had the experience that theory, ironically, can be difficult to discuss in the higher education (HE) context. Such discussions can sometimes lead to a combative situation in which an academic from one theoretical background assumes the political and epistemological superiority of his/her own distinctive theoretical paradigm. We decided to call the series 'Demystifying Theory', since this term would serve a dual purpose. Firstly, it would involve an approach where contributors could be open about why a particular theorist had come to have such personal significance to them as academics interested in pedagogic change. Secondly, in revealing our personal investments in a particular theorist, we hoped that this approach, set within the context of respect for others' contrasting passions, might induce sometimes opaque theory to spring into life and vivacity.

At the time of writing this, three theoretical perspectives have been discussed: Andrew Lambirth talked about 'Marx and Me'; I talked about 'Foucault and Me'; and Priti Chopra talked about 'Spivak and Me'. The seminars have been very successful and we hope our pleasure in sharing ideas and the friendly discussions that ensued might be a model for the extension of the seminar series into the next academic year. We have discovered the School of Education has a panoply of theorists who inform the thoughts and practices of colleagues. In this article I take the opportunity to address some of the issues explored in my own talk on Foucault.

I briefly rehearsed the nub of the contention between Foucauldian and Marxist educational theorists with regard to how to analyse political power. This is pertinent to my own 'relationship' with Foucault and my proposal that his body of work provides a fertile conceptual 'toolkit' for critical analysis of the policies and practices of education. Since the purpose of this paper is not to delve too deeply into theory, I simplify the theoretical positions of Marx and Foucault. I apologise in advance for the necessary reductionism of complex and subtle arguments.

\section{Two models of power}

The conflict between Marxist and Foucauldian theorists tends to wander down the following well- trodden path. Contemporary Marxists argue the determining force that drives modern Western liberal democracies, and why we do not always function in a democratic way, is global capitalism. The capitalist system, in being shackled to democracy, rides roughshod over the humanitarian liberal democratic ideal of equity of opportunity. Capitalism is not a static mode of social and economic organisation; rather it 
is mobile and ever changing. Nevertheless, whether it is the capitalism of the industrial 19th century or the global capitalism of the 21 st century, it has the same core internal dynamic. The current education system, from primary education through to $\mathrm{HE}$, is an 'ideological state apparatus' that mobilises the vested interests of global capitalist accumulators and the privileged few. The casualties are the ordinary people - the non-privileged girl or boy, woman or man - who gets swept up in its wake. The current education system largely trains the masses for the reproduction of the capitalist system and the result is a diminution of the individual's intellectual potential.

It is clear that the economic/social/political model of power deployed by Marxist theory, whether it is the power that belongs to the capitalist, the student or the education system itself, conceives of power as sovereign. By sovereign power I mean it is made up of the following components:

a binary division demarcates those who possess power and those who do not

power is a possession that is held by one group, the privileged class, and it is exercised negatively 'over' the less fortunate

the exercise of power is accomplished by ideology

oppressed classes, through becoming conscious of the unjust social conditions of their existence, can overthrow power and be free.

Foucault, in contrast, argues that a model of power as sovereignty is anachronistic since it does not fully account for how the social control of population is exercised in advanced liberal democracies. The sovereign power described by Marxism refers to the kind of power exercised by the pre-modern monarch or sovereign. Foucault's $(1977 ; 1978)$ pivotal claim is that since the 19th century, power has operated not so much negatively, in the form of power 'over' individuals, but productively and from 'below', through normalisation at the deepest level of an individual's self-identity. Disciplinary normalisation occurs at local sites, for example within the family, the education system, medicine, etc. These institutions interact with 'official' human science knowledge that constitute human beings around a psychological axis of normalcy/abnormalcy. Discourses of normalcy set up a dynamic in which human beings self-police or discipline themselves around the question: 'Is my behaviour normal'? Liberal democracy is a political system originally conceived in Europe in the 18th century in opposition to monarchical rule and was constituted around the alleged freedom of individuals to be self-determining. However, since structure is a requirement of all social order, democracy can only function if disciplinary control is exercised but not experienced as disciplinary. It is mobilised by the way individuals 'freely', through self-surveillance, constitute themselves around the axis of normalcy/abnormalcy.

Foucault and Marx both set out to theorise the same problem, namely how human beings 'consent' to being governed when government does not serve the interests of their freedom. Although each argues that human consciousness is determined by its social, political and historical context, Foucault's methodological approach is more radical than Marx's approach. Marx argues that the individual consciousness has been historically acted upon by the ideology of class relations; so that only in a future society, when class relations are abolished, i.e. in communism, can human beings have 'true' (nonideological) consciousness of the conditions of their existence. Foucault (1982), similarly, argues the individual is always and inescapably discursively constituted or 'subjectified'. There is a play on the term subjectification: on the one hand, in liberal democracy, we are subjects 'of' our own lives; 
on the other hand we are subject 'to' a disciplinary power composed around self-regulation and our 'voluntary' adherence to normalising discourses. He demonstrates that in the contemporary period we are all constituted by the liberal institutions of the family and the education system, for example, and the normalising knowledges or discourses that inform them. These sites conjoin and consolidate from the bottom up with larger structures of state power in a network whose overarching effect is oppression. Power does not 'only' emanate from 'below', it is exercised from above too, but sovereign power would be ineffectual in a democratic political system if we had not already been normalised in our personal lives to comply with it or even want it!

Foucauldian ideas were introduced into critical thinking about education (Marshall, 1989, 1996) as a complement to or substitute for Marxist critical thought in the late 1980s. Over the years there has been something of an entrenchment or polarisation of theoretical positions. Two camps were created: those who welcomed Foucault's ideas as a fertile theoretical development of Marxist thought; and those who resisted Foucault's ideas as reactionary and unable politically or ethically to effect change. This latter reaction is exemplified by Apple's (1995) response to the analysis of the relationship between the state and $\mathrm{HE}$. He claimed that a considerable portion of critical education research was taken up in the late 1980 s and the early 1990s by "an upwardly mobile fraction of the new middle class within the academy ... [which] has lost all but the most rhetorical connection with the struggles against domination and subordination at universities" (1995:xi). The emphasis on discourse he described as "the linguistic turn", whereby social theorists have forgotten "the world inside and outside education is not only a text. There are gritty realities out there, realities whose power is often grounded in structural relations that are not simply social constructions" (1995:xiii). Apple deployed Marxist theory to help him in the task which he urged us all to carry out, namely "to avoid losing sight of these realities in the economy and the state" (1995:xiii).

I argue Apple's characterisation of Foucauldian thought as retrograde and ineffectual. It exemplifies an established orthodoxy in Marxist thought, and one that mistakes the term discourse, assuming it means language. Discourse is more than language: it is the inter-relationship between what we say (including what 'official' knowledges say) and power. As a scholar analysing HE from a Foucauldian perspective how do I understand my own theoretical activities in the face of this critique?

\section{A Foucauldian analysis of $\mathrm{HE}$}

Firstly I argue that a Marxist view that rejects the political potency of the discursive production of subjectivity fundamentally misunderstands Foucauldian thought. To give an example: I was challenged by a colleague recently who suggested that not many people in the School of Education would accept that power resides at the 'bottom' and is exercised 'upwards'. However, my colleague also reasoned that top-down power and compliance enforcement are still active but that other tactics are now exercised less overtly through normative re-educative approaches rather than power-coercive approaches. He argued contemporary politics have set a new 'normalcy', for example over the roles of traditionalist elitist universities and modern universities, a normalcy that is projected as the natural order. He posited that there has been a raft of legislation by the power-holders, based on fear, in an attempt to control through surveillance and enforce compliance to a concept of the 'good citizen' which is both racist and classridden. Interestingly, this interpretation of the contemporary government of $\mathrm{HE}$, which sets out to counter Foucault's proposition that power functions from 'below', actually exemplifies it. 
Foucauldian theorists do not deny that in HE power functions in a 'top-down' mode and that elite and 'new' universities distribute students according to class and race. Clearly power functions coercively by coalescing around certain groups to form hierarchical divisions, as witnessed by the preponderance at new universities of working-class and ethnic minority students. However, whilst this may demonstrate power 'over', the model of power as sovereignty cannot be taken as an example of the quintessential operations of modern state power, global capitalism and their relationships to HE. If power is conceptualised as sovereign it obfuscates technologies of power which discursively constitute university members - students and tutors - as particular kinds of normalised subjects. Although $\mathrm{HE}$ is the outcome of the complex relations of advanced liberalism with global capitalism it can only successfully govern by governing individuals through discourses of 'freedom'.

In doing so Foucauldians do not reject the Marxist concern with material conditions. On the contrary: they re-configure materialism (Olssen, 1999). In contrast to Marxist discourses, Olssen argues a Foucauldian approach does not represent materialist processes as determined primarily by the economic base, or describe the 'fit' between state power and capitalist interests in terms of the individual's oppression by a power imposed from 'above'. With regard to the discursive construction of the student, a Foucauldian analysis demonstrates how students take upon themselves the idea of responsible citizenship through educational self-maximisation. This shows how the contemporary relationship between university qualifications and personal enhancement and career development has historically been put together, the practices which support it, and the relations of power that constitute particular kinds of students (who for example currently demand HE as their 'right' despite the increase in fees). With regard to the discursive construction of tutors, a Foucauldian analysis demonstrates how corporatist management practices involve individuals in implicating themselves in their own government, where self-government occurs at the intersection of technologies of discipline and technologies of self. The market, management, appraisal and performance are 'regimes of truth' through which tutors, even though they partially demonstrate resistance, are both governed and govern themselves 'voluntarily'.

\section{Foucauldian politics}

A Foucauldian approach to power provides a new political imagination for theorists working for progressive social and educational change. It suggests abandoning the idea that as human subjects we can emancipate ourselves by totally escaping from power. Unlike a traditional Marxist analysis, this approach does not involve revolutionary ideas about overthrowing the contemporary organisation of contemporary HE, since this would probably be impossible. Freedom lies in reflecting upon the micropolitics of our discursive 'subjectification' within HE as well as the macro-politics, and how these micropolitics produce us as governable subjectivities. On the basis of that reflection, we can act upon the self and join up with others to conduct the self 'differently'.

Where I once felt disturbed by Foucault's idea that individuals are never 'free' in the sense that we can become autonomous individuals outside of conceptual systems - or what Foucault (1980) calls power/knowledge - I now take comfort in this view. It provides a new political imaginary of the modes of resistance needed if, as theorists working for progressive social and educational change, we are to challenge power in its various manifestations. Freedom exists in our ability as subjects to comprehend how we have been discursively constructed - the task Foucault (1994) describes as a critical ontology of the self - and to become political activists at local sites of subjectification. Since modern power is 
productive of humanist subjectivity, the political and ethical task is not to try to liberate the individual from the state and from the state's institutions, but to liberate us from the type of individualisation which is linked to the state (Foucault, 1991).

\section{Conclusion}

Foucault has been utterly transformative in my intellectual, political and emotional life. I first 'met' him some years ago when I was undertaking an MA in Culture, Communication and Society. Quite frankly I didn't like him and found his 'oeuvre' depressing, arcane and seemingly without moral purpose.

Moreover Foucauldian theorists were, in my view, academic dilettantes arrogantly impervious to any criticism. I set out to demonstrate from a feminist (standpoint epistemological) perspective, influenced by Marxism, that Foucault's methodology was incapable of addressing the 'gritty realities' of oppression, reneging on social responsibility by playfully taking 'discourse' as its object. However, like one of those children's toys shaped like a man with a round bottom and no legs that becomes upright when you knock it down, the more I targeted Foucault's thought the more it re-asserted itself for further consideration.

Foucault asked me to consider at least temporarily changing theoretical directions since fostering doubt about Marx's methodology is not perilous if one can retrace one's steps. Thus began a long journey that witnessed me as an initial unhappy traveller. Rather than engaging in a vacuous project, I now experience his work as providing a powerhouse of tools which help theorists analyse the most serious social and political problems of our day. As such he is an intellectual giant who takes up his place in the pantheon of those giant thinkers (including Marx) who, across history, have helped us, against the grain of traditional or orthodox thought, to 'see and act otherwise'.

\section{References}

Apple, M. (1995) Education and Power. New York and London: Routledge.

Foucault, M. (1980) Michel Foucault: Power/ Knowledge, Selected Interviews, edited by Gordon, C. Harvester. London: Wheatsheaf.

Foucault, M. (1991) Governmentality. In: Burchell, G. et al. The Foucault Effect: Studies in Governmentality. London: Harvester Wheatsheaf.

Foucault, M. (1994) What is Enlightenment? In: Rabinow, P. (ed.) Michel Foucault: Ethics, The essential works of Foucault 1954-1984.

Olssen, M. (1999) Michel Foucault: Materialism and Education. Wesport: Bergin and Garvey. 